\title{
RFID-over-Fiber system for agricultural exploitations - Wireless track and trace with range extension using optical fiber
}

Madsen, Peter; Suhr, Lau Frejstrup; Cavalcante, Lucas Costa Pereira; Vegas Olmos, Juan José; Tafur Monroy, Idelfonso

\section{Published in:}

Proceedings of 2015 IEEE International Topical Meeting on Microwave Photonics

Link to article, DOI:

10.1109/MWP.2015.7356672

Publication date:

2015

Document Version

Publisher's PDF, also known as Version of record

Link back to DTU Orbit

Citation (APA):

Madsen, P., Suhr, L. F., Cavalcante, L. C. P., Vegas Olmos, J. J., \& Tafur Monroy, I. (2015). RFID-over-Fiber system for agricultural exploitations - Wireless track and trace with range extension using optical fiber. In Proceedings of 2015 IEEE International Topical Meeting on Microwave Photonics IEEE. https://doi.org/10.1109/MWP.2015.7356672

\section{General rights}

Copyright and moral rights for the publications made accessible in the public portal are retained by the authors and/or other copyright owners and it is a condition of accessing publications that users recognise and abide by the legal requirements associated with these rights.

- Users may download and print one copy of any publication from the public portal for the purpose of private study or research.

- You may not further distribute the material or use it for any profit-making activity or commercial gain

- You may freely distribute the URL identifying the publication in the public portal 


\title{
RFID-over-Fiber system for agricultural exploitations
}

\author{
Wireless track and trace with range extension using optical fiber
}

\author{
P. Madsen, L. Suhr, S. Rodriguez, J.J. Vegas Olmos and I. Tafur Monroy \\ Technical University of Denmark, Department of Photonics Engineering \\ Ørsted Plads, Building 343, Kgs. Lyngby, 2800, Denmark.
}

\begin{abstract}
This paper proposes and demonstrates an RFIDover-Fiber wireless track and trace system using active RFID tags and operating over distances up to $30 \mathrm{~km}$ of optical fiber and 35 meters of wireless readability.
\end{abstract}

Keywords - component; microwave photonics, radio-over-fiber, RFID, sensing.

\section{INTRODUCTION}

Agricultural exports in Denmark account for around $20 \%$ of all commodity exports; circa 64 percent of the land area is being used for production. Particularly, production of pigs and pig meat is a main area of specialization in Denmark, where $90 \%$ of the production is exported. These includes pigs for the British market for bacon production, heavy pigs for the German market and pork cuts with outstanding high levels of food safety for the Japanese market [1]. In 2015, the Danish government launched the Månegrisen project, aiming at developing novel technologies to improve the animal welfare, reduce emissions and optimize the utilization of resources in the pig industry. One of the main challenges in pig production, and poultry overall, is the localization of the animals while they are roaming free. This paper proposes to improve the pig production by making a smart pigsty that provides information in the individual pig instead of the whole sty. This is realized by using radio frequency identification (RFID) to collect and send different information about the pig to a central knowledge center. This paper focuses on the extension between the RFID reader and antenna together with positioning and readability of RFID tags [2]. The wanted knowledge gathered from the RFID tags is among other things, the position of the pig at given times during the day. Today RFID is only used in pigsties to optimize the food per growth of pigs. This is done with an RFID reading feeder that only allows one pig to enter the feeder. In the feeder, the pig is given a few grams of food. When is has eaten the food it can enter again for more food. The pig can do so until a certain daily ration has been reached. This ration is set to give maximum the growth, while lowering food consumption. These principals from the food per growth optimization can be carried over to the medicine consumption by the use of a smarter RFID system. Sickness in a pigsty is normally spotted in very late stages and the whole sty has to be treated with medicine, normally given in the water. With an RFID system that can help the farmer spot abnormal behavior based on daily activity pattern, for example if a pig have been lying in the same spot all day, while the other pigs have been active or it has not been positioned near the drinking/ feeding trough, then sickness can be spotted in time for single pig treatment. This drastically lowers the medicine in the pigs and overall consumption. Another good case where RFID can be a help is when sending pigs to the slaughter. Each pig qualified for slaughter is weighted and if it to be slaughtered it is marked with a spray paint tag. Many farms send their prepared pigs to the slaughterhouse with the same truck and it is up to the slaughterhouse to keep track of which pigs belong to which farm based on the spray paint tag. With RFID tags, it is not necessary to mark the animals. When the pig is off the scale, the weight is stored in the RFID tag, and the unique number is registered to the specific farm. The slaughterhouse could use the same RFID tracking system as the farm. This allows the slaughterhouse to always, keep track of the pig's size and numbers of pigs from the farms. After slaughter the tags could simply be delivered back to the farm by mail. This is just some of the few benefits that improve the very important pig industry of Denmark.

This paper demonstrates a platform in where a large quantity of antennas can provide readings of active RFID tags placed on wild-roaming animals. The platform is shown in Fig. 1. RFID over fiber has been discussed previously [3], and its advantages clearly demonstrated, i.e. large antenna count, high location precision, and low computational complexity.

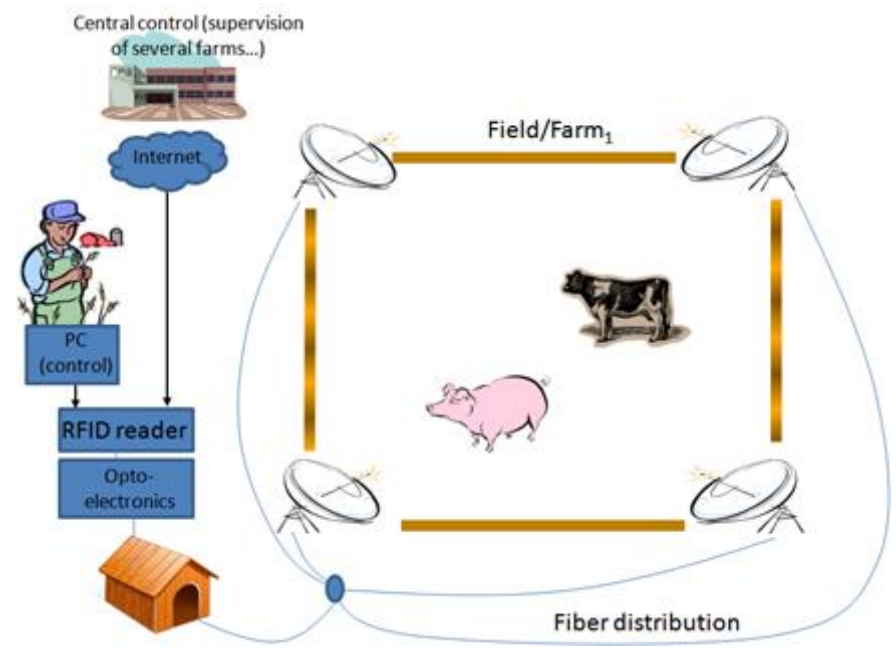

Fig. 1. System scenario in the context of the "Månegrisen" project. 